\title{
Innovation in the Global Age: Implications for Business and Management in the Knowledge Economy
}

\author{
Anshuman Prasad ${ }^{1} \&$ Pushkala Prasad ${ }^{2}$ \\ ${ }^{1}$ College of Business, University of New Haven, Connecticut, U.S.A. \\ ${ }^{2}$ Department of Management and Business, Skidmore College, Saratoga Springs, U.S.A. \\ Correspondence: Anshuman Prasad, College of Business, University of New Haven, 300 Boston Post Road, West \\ Haven, CT 06516, U.S.A. Tel: 1-203-932-7124. E-mail: aprasad@newhaven.edu
}

Received: October 27, 2013

Accepted: November 4, 2013

Online Published: November 8, 2013

doi:10.5430/ijba.v4n6p82

URL: http://dx.doi.org/10.5430/ijba.v4n6p82

\begin{abstract}
The current era of globalization is characterized by far-reaching shifts in the economy as well as in a variety of other spheres of human activity. The present article focuses upon innovation, an activity that is viewed as crucial for business success in today's knowledge economy, and which seems to be in the middle of an extensive process of global restructuring. The article begins with an overview of the nature of the knowledge economy, highlighting in the process the significance of the digital revolution, the rising knowledge-intensity of economic activities, the changing relationship between services and manufacturing, and the growing importance of tacit knowledge. Next, the article examines some of the major structural changes that are transforming the field of innovation in a rapidly globalizing knowledge economy, and while so doing draws attention, in particular, to certain changes in scholarly understanding of the innovation process, the rise of considerable innovation activity outside the traditional centers of innovation, and the ongoing globalization of innovation. Finally, the concluding section of the article discusses some implications of these developments for business and management.
\end{abstract}

Keywords: innovation, knowledge economy, globalization

\section{Introduction}

Scholars and practitioners of business and management today seem to be well aware that we are living in an era of intensifying globalization. In broad terms, globalization may be conceptualized as a highly complex and fast-paced process of worldwide transformations resulting from growing cross-border interactions, integration and inter-dependence in a variety of spheres, including economic, cultural, demographic, ideological, technological, and so on (Appadurai, 1996; Friedman, 2005; Held \& McGrew, 2003; Inda \& Rosaldo, 2008; Prasad \& Prasad, 2006). Analysts often suggest that the current era of globalization needs to be viewed as a radical period of transition that might be leading to the emergence of a new world system (Dicken, 2003; United States National Intelligence Council [USNIC], 2012; Wallerstein, 2000; Wilson \& Purushothaman, 2003).

In this regard, analysts who believe that globalization might be creating a new world system frequently point out, among other things, that the overall center of gravity of the global economy seems to be progressively moving away from the West and toward the 'Third World' (or, more specifically, toward Asia): for instance, whereas in 1980, the 'developing countries' accounted for only $31 \%$ of the total actual production of goods and services worldwide, today those countries produce fully $50 \%$ of the global total; and similarly, while Asia's share of the total goods and services actually produced in the world was only $18.6 \%$ in 1950, that proportion grew to $38.9 \%$ by 2011 (Maddison, 2007; International Monetary Fund [IMF], 2013; World Bank, 2012). Along parallel lines, the geographical structure of international trade is undergoing significant changes as well, and as a result, the relative significance of the Western countries in global trade seems to be steadily declining. For example, between 2000 and 2011, the share of global merchandise exports attributable to the largely-Western group of G-7 countries (Canada, France, Germany, Italy, Japan, the U.K., and the U.S.A.) shrank by about $28.7 \%$, while the G-7 share of merchandise imports declined by 23.9\% (World Trade Organization [WTO], 2012). Scholars have noted that somewhat similar world systemic shifts appear to be occurring in cultural, demographic, technological, and other areas as well (Held \& McGrew, 2003; Inda \& Rosaldo, 2008). 
In this connection, many analysts contend that the intensification of world systemic transformations during recent decades seems to have been accompanied also by the growing importance of, what has come to be called, the knowledge economy (Drucker, 1993; Powell \& Snellman, 2004). It is important to point out here that the relationship between globalization and the increasing salience of knowledge in the economy is a complex and highly debated issue, and sweeping generalizations in the matter are clearly not warranted. Indeed, skeptic voices have raised some fundamental questions about the notion of the knowledge economy (see, e.g., May, 2002). Nevertheless, a number of scholars have long been suggesting that different parts of the world appear to be in the midst of a transition from an industrial economy (i.e., an economy primarily organized around the deployment of labor, capital, land and natural resources with a view to producing mostly physical goods) to a 'post-industrial' economy in which knowledge, both as input as well as output of economic activities, comes to occupy a unique position of significance (Bell, 1973; Castells, 2000; Drucker, 1993). Generally speaking, the competitive strength of a knowledge economy is seen to fundamentally depend upon the quality of its human capital and its capacity for continuous innovation (Adner, 2012; Radjou, Prabhu, \& Ahuja, 2012).

Located at the interface between deepening globalization and a continually expanding knowledge economy, the present article examines some of the structural shifts that are transforming the field of innovation in the contemporary world, and implications thereof for business and management. In so doing, the paper addresses a number of inter-related issues of considerable relevance for both researchers and practitioners, including the complexity and significance of globalization, the macro-level shifts occurring in the broader structures of the global economy, and the importance and intricacies of innovation in a rapidly evolving world marked by growing value of knowledge as well as changing nature and structure of innovation itself. Developing a sound understanding of these deeply inter-linked concerns would appear to be essential for business and managerial success in today's increasingly complex world. In what follows, we first briefly examine the nature of the emerging knowledge economy, and then proceed to a discussion of innovation in the context of a knowledge economy that is getting increasingly globalized.

\section{Globalization and the Emerging Knowledge Economy}

In current research literature, the concept of knowledge economy is often traced back to Machlup's (1962) influential economic analysis of the production and distribution of knowledge in the United States. Since the publication of Machlup's study, scholarly discussions of the knowledge economy have literally mushroomed, ranging over a variety of theories, as well as an array of somewhat overlapping concepts that include (in addition to "knowledge economy") such notions as the "digital economy", the "new economy", the "informational (or, information) economy", the "post-industrial economy", the "knowledge-based (or, knowledge-oriented) economy", and so on (Bell, 1973; Castells, 2000; Dolfsma \& Soete, 2005; Godin, 2006; Leydesdorff, 2006; Organization for Economic Cooperation \& Development [OECD], 2001). In this section of the article, however, we will mostly provide a broad outline of the overall nature of the knowledge economy, without necessarily discussing the finer distinctions that characterize the host of loosely related concepts that have emerged to refer to this phenomenon, or the individual contributions made by the different theories that seem to abound in this area of scholarly research.

Briefly stated, the concept of knowledge economy may be seen as referring to the idea that more and more sectors of contemporary economy in various parts of the world appear to be based on ever-increasing levels of production, use, and dissemination of knowledge and information, with the result, seemingly, that "knowledge does not simply govern ... economic growth"; rather knowledge itself comes to serve as "the principal activity of the economy" (Kumar, 1995: 11; emphasis added). It needs to be noted here that knowledge, of course, has been of central importance in economic activities throughout human history. Hence - and notwithstanding the distinction commonly made in current research literature between 'codified' versus 'tacit' knowledge (discussed later in this article) - the notion of 'knowledge' embedded in the writings on knowledge economy largely, though by no means exclusively, refers only to the knowledge that subscribes to a Cartesian epistemology. Not surprisingly, therefore, the definition of knowledge informing current research on knowledge economy mostly tends to exclude what is now known as 'traditional' or 'indigenous' knowledge (Harding, 2011).

\subsection{The Emerging Knowledge Economy: Key Features}

The idea of the knowledge economy is intimately linked to the dramatic advances made during recent decades in the field of information and communication technology (ICT). The so-called digital revolution is frequently seen by the analysts of knowledge economy as a key 'enabler' that has, on the one hand, significantly facilitated and speeded up the generation, utilization, and distribution of knowledge and information and, on the other hand, served to deepen the incorporation of knowledge in different products and services, as well as, in various spheres of economy and society. Consequently, the knowledge economy has come to be viewed as an economy that is characterized by the 
growing knowledge-intensity of economic activities. The rising knowledge-intensity of economic activities in the emergent knowledge economy may be seen as manifesting itself in a variety of ways, including the changing nature of different products, shifting national and international economic structures, alterations occurring in employment patterns, growing R\&D spending and patenting, and so on.

For instance, scholars point out that, increasingly, a manufactured product today (e.g., a car) is "less and less the product of ... fabrication and more a smart machine" incorporating high levels of digital technology (Powell \& Snellman, 2004: 201; emphasis added). Similarly, for a number of years now in many countries, manufacturing in the knowledge-intensive (or, "high-tech") industries (e.g., computers, aerospace, telecommunication equipment, pharmaceuticals, and the like) seems to have been growing at a faster pace than manufacturing in non-high tech sectors, with the result that the share of high-tech manufacturing in total manufacturing has been rising in several economies. For instance, in the United States, the share of high-tech manufacturing in total manufactured output, which was $10.4 \%$ in 1980 , had grown to $13 \%$ by 1989 , and $15 \%$ by 1995 (National Science Foundation [NSF], 1998). Arguably, such a trajectory continues to persist in the United States to this day, and several other economies in different parts of the world seem to be exhibiting somewhat similar tendencies.

The growing knowledge-intensity of economic activities is said to be revealed also in the shifts that seem to be taking place in the area of employment patterns in various countries. In the United States, for instance, while aggregate private sector employment grew by only 3.7\% between 2004 and 2011, employment in the high-tech sector increased by $11.1 \%$ during that period (Bay Area Council Economic Institute [BACEI], 2012). Similarly, it is projected that, during the years 2011-2020, while total employment in high-tech industries in the United States will likely grow by $16.2 \%$, employment in the U.S. non-high tech industries might increase by only $13.1 \%$ (BACEI, 2012). Along parallel lines, growing spending on $R \& D$, as well as increases in patent filings, are also seen to offer support for the idea that the knowledge-intensity of different economies might be rising. For instance, during the 15-year period between 1996 and 2009, the United States doubled its total R\&D spending, while a group of ten Asian countries including China and India registered a three-fold increase (Reich, 2012). Likewise, according to data available with the United States Patent and Trademark Office (USPTO), the total number of domestic patents awarded by the USPTO between the years 2000 and 2012 grew by $38.3 \%$, while during the same period, U.S. patents awarded to patent filings originating in China indicated a close to nine-fold increase, and those awarded to filings originating from India exhibited a more than thirteen-fold growth.

The emerging knowledge economy seems to be characterized by a variety of other important features. For instance, in terms of organizational forms, the knowledge economy is said to be distinguished by flexible organizations having flatter structures with relatively minimal middle-management intermediation between senior executives and workers who, in turn, tend to be configured around customer-oriented teams. These workers, moreover, are generally required to avoid narrow compartmentalization and restricted specialization, and to possess the necessary skills and capabilities for multi-tasking, team working, and developing personal relationships. Besides, such organizations seek added agility in operations also by means of participating in a variety of national/international networks and strategic alliances.

Furthermore, in some respects, the knowledge economy may be seen to be exemplified also by the growing importance of the services sector (e.g., advertising and mass media; education; financial services like banking or insurance; healthcare; professional services such as accounting, consulting or law; telecommunication services and so forth). In this regard, it is important to emphasize that - notwithstanding the dramatic growth during recent years in the relative share of services in the gross domestic product (GDP) of many countries - it would be erroneous to believe that the knowledge economy implies a service economy (i.e., an economy in which, at a somewhat fundamental level, manufacturing has ceased to be of importance). Nevertheless, scholars note that a knowledge economy does seem to indicate an economy in which, at least partly as a result of greater incorporation of digital technologies in different products and services, manufacturing and services sectors seem to exhibit a close and symbiotic relationship, and the manufacturing versus services distinction tends to get somewhat fuzzy (Powell \& Snellman, 2004).

It might be worthwhile noting here that the knowledge economy appears to be marked also by certain changes occurring within the domain of knowledge itself. As alluded to earlier, current research on knowledge economy frequently highlights the distinction between two different types of knowledge: (a) codified or explicit knowledge - i.e., formalized knowledge, consisting of theories, guidelines, facts and the like, which may be found in textbooks, research journals, databases, documents and so forth, and which is easy to store, retrieve and transmit - and (b) tacit knowledge, or knowledge that is relatively subjective, experience-based, and 
context-dependent and, as a result of such characteristics, is much more difficult to communicate (Nonaka, 1991, 1994; Nonaka \& Takeuchi, 1995). Tacit knowledge, in turn, may be seen to be of different types including, for instance, knowledge that might be embodied in individual skills, or be embedded in different organizational routines, or be part of an organization's beliefs, norms or values, and so forth.

Following past scholarship on knowledge (e.g., Polanyi, 1966), researchers often view 'codified knowledge' and 'tacit knowledge' as being part of a continuum, rather than in terms of a strict dichotomy that rigidly separates the two. At one extreme of that continuum, codified knowledge merges with information, and takes on the nature of a commodity. Scholars believe that, partly as a result of the ICT revolution, the emerging knowledge economy is characterized by significant intensification of the process of knowledge codification. As a result, increasing volumes of knowledge are getting commodified, and are now much more easily available to large numbers of people and companies worldwide. In such a world of relatively abundant codified knowledge, it is tacit knowledge that increasingly differentiates one firm or national economy from another and, hence, becomes a factor of crucial significance for continuous innovation and competitive success. The next section of the article discusses some key aspects of innovation in a globalizing knowledge economy.

\section{Innovation and the Globalizing Knowledge Economy}

Although analysts often rely upon narrower definitions of innovation-definitions that view this activity largely in terms of R\&D and related endeavors that result in the development of new products, processes, services, and/or organizational structures - innovation, in more comprehensive terms, may be conceptualized as a phenomenon that "involves thinking differently, creatively and insightfully to create solutions that have an impact in terms of social and economic value" (National Innovation Council of India [NICI], 2011: 3). In economics, the valuable nature of innovation has long been recognized in the writings of thinkers like Adam Smith, Karl Marx, Joseph Schumpeter and others. Moreover, as already noted, with deepening globalization and the ongoing expansion of the knowledge economy, innovation has come to be seen as a key factor for success in the 21 st century. Such renewed attention to innovation, furthermore, has been accompanied also by important changes with respect to: (a) the scholarly understanding of the nature of the innovation processes itself, as well as (b) the structural organization of the process of innovation at the global level (Archibugi \& Iammarino, 2002; Cassiolato \& Vitorino, 2011; Ernst, 2006).

\subsection{The Nature of Innovation Process}

As regards the nature of the process of innovation, conventional scholarship largely tended to subscribe to the linear (or, 'science-push') model of this phenomenon, which regarded scientific research as its principal driver, and saw the innovation process as unfolding through a somewhat mechanistic sequence of fairly distinct phases starting with (a) research, and proceeding to (b) product development and, thereafter, finally moving on to (c) taking the product to the market. As distinct from the linear model, however, innovation nowadays is generally viewed by many scholars as a much more complex, non-linear, and interactive process involving a number of (a) actors, as well as (b) sources of ideas, both of which may be found inside as well as outside the focal organization where a specific piece of innovation might actually come to materialize. Such non-linear and interactive notion of innovation has given rise also to the idea that innovation needs to be understood in the context of a variety of systems of innovation at different levels, such as 'technological', 'regional', 'national', 'supra-national', and so on. In particular, several scholars seem to especially emphasize the importance of the national innovation system (NIS) for promoting innovation in a country (Cassiolato \& Lastres, 2011; Lundvall, 1992, 2007; Nelson, 1993).

The NIS perspective considers innovation to be an interactive and non-linear process, while at the same time, also emphasizing the context-specific and localized character of the processes that might drive innovation in a country. Hence, according to this perspective: (a) the NIS of a country is regarded as a locally-embedded network of a variety of institutions and, furthermore, (b) innovation is viewed as being produced via the various internal and/or external interactions of the institutions comprising a given NIS. Not surprisingly, different authors have tended to conceptualize the idea of NIS in different ways. Generally speaking, however, while some researchers continue to lean toward a relatively narrow view of NIS (which sees an NIS largely in terms of a country's science and technology-related institutions and policies, R\&D activities, and so on), many scholars now seem to favor a broader view of NIS (Cassiolato \& Lastres, 2011). The latter approach seeks to offer a more comprehensive understanding of the concept by means of: (a) including a wider set of institutions in its conceptualization of NIS, and (b) by also taking into account a variety of contextual factors that might impact those institutions. Simplifying somewhat, according to the broad view, the NIS of a country may be said to consist of: (a) organizations in the country's different economic sectors, (b) organizations involved with education, scientific and technological research, and so on, and (c) institutions responsible for public and private policy formulation, financing, governmental regulation, and 
such like, all of which, in turn, are seen as being influenced not only by (d) structures of demand, consumption, income distribution and so forth, but also by (e) social, cultural, historical, macroeconomic, geopolitical and similar other forces (Cassiolato \& Lastres, 2011).

\subsection{Global Restructuring of Innovation}

In addition to changes in the scholarly understanding of the process of innovation, the field of innovation seems to be also in the midst of large-scale global restructuring. Although there would appear to be a variety of forces responsible for the global restructuring of innovation currently underway, that restructuring may be seen as being primarily driven, arguably, by two somewhat overlapping processes: (a) the rising profile of a number of NISs outside the G-7 countries, and (b) the ongoing globalization of innovation. With respect to the rise of NISs outside the G-7, the example of the BRICS group might be instructive. In recent years, the BRICS countries (Brazil, Russia, India, China and South Africa) have come to be recognized as actors of considerable significance on the global stage (Pricewaterhouse Coopers [PWC], 2013; Wilson \& Purushothaman, 2003). By way of introduction, we may note here that collectively the BRICS group spans over roughly $30 \%$ of the earth's total geographical area, while forming about $42 \%$ of the world's aggregate population (mid-2013 population estimates). The BRICS countries constitute a grouping of rising economic powers, and with a combined GDP of about $\$ 23.7$ trillion in 2012, the BRICS group accounted for approximately $28 \%$ of total global GDP on a Purchasing Power Parity basis (World Bank, 2013). In comparison, the G-7 group's share of global GDP in 2012 stood at roughly 37\% (World Bank, 2013). The BRICS group, however, is growing at a considerably faster pace than the G-7, and there appears to be broad agreement among analysts that this differential growth trajectory is likely to persist for the next four to five decades (OECD, 2012). Hence, the BRICS group is projected to become a much larger economic force than the G-7 group over the next several years. Not surprisingly, given their growing importance, the BRICS belong to the larger G-20 group that has emerged - in the wake of the financial crisis - as the principal multilateral forum for steering the international economy.

Primarily owing to their different historical and cultural experiences, the individual BRICS countries exhibit many differences in their approach toward innovation and the knowledge economy. Such differences notwithstanding, all the BRICS countries seem to have made considerable efforts during the past decades with a view to developing robust science, technology and innovation (STI) policies and strengthening innovation capabilities. Interestingly, the approach adopted by the BRICS for developing STI policies tends to significantly differ from the STI policy model generally followed by the OECD countries, mainly because the BRICS group's approach often includes "policies that are not geared directly to STI but have a significant impact on innovation outcomes" (Cassiolato \& Lastres, 2011: 23). For instance, in several BRICS countries, STI policies are explicitly or implicitly linked to the broader national goal of 'inclusive development' aimed at achieving a more equitable distribution of the gains of economic growth and innovation (George, McGahan \& Prabhu, 2012; NICI, 2011).

Needless to say, the BRICS group has been enhancing its focus on R\&D as well: for instance, between 2000 and 2008 , total R\&D expenditure in the BRICS increased by about $70.6 \%$, and further increases are expected (Cassiolato \& Lastres, 2011). Similarly, the BRICS have been placing increased emphasis also on the development of high-quality public and/or private research institutions. It needs to be noted here that, for a variety of reasons, many of the BRICS group's contributions to innovation continue to remain largely "invisible to consumers around the world" (Kumar \& Puranam, 2012: 8); as Mathew (2010: 79), for instance, points out: "very few people know that Microsoft's new search engine, Bing, was developed in India." However, observers believe it to be only a matter of time before the innovations occurring in the BRICS gain greater international visibility. All in all, in other words, the BRICS group appears to have established itself as a factor of growing influence in the area of innovation, and in so doing, contributed significantly to the ongoing global restructuring of innovation. Alongside the BRICS, many other non-G-7 countries also seem to be steadily working to raise their profile in the field of innovation.

If the advances made by the BRICS and other 'developing' countries represent one key driver for the current restructuring of innovation, another factor responsible for the said restructuring consists of the ongoing globalization of innovation, involving the construction of a variety of global innovation networks (GINs) by means of cross-border outsourcing and/or offshoring of innovation activities. As distinct from past organizational practices that tended to concentrate innovation related work in a firm's 'home' country (Pavitt \& Patel, 1999), the emerging practice of organizing innovation via GINs is characterized by wide-spread geographical dispersal of innovation activities across multiple national borders, and represents the response of the large business corporation to important shifts in relative innovative capacity at the global level. For instance, Intel Corporation no longer finds it strategically viable to confine its innovation related work within the United States alone; rather Intel conducts that work via a GIN that 
includes a networked set of R\&D laboratories in the U.S., China, India, Israel, and Russia (Ernst \& Hart, 2008). Hence, through its GIN, Intel is able to tap into foreign centers of excellence and draw upon a range of valuable high-tech capabilities available in geographically distant locations and, thereby, plug important gaps in its own in-house knowledge-related resources and capabilities.

Currently, it would appear that the companies initiating the construction of GINs mostly tend to be firms from the United States, Japan, or Europe. Increasingly, however, business firms from countries like South Korea, Taiwan, China, and India also seem to be structuring their own GINs. At present, the development of GINs seems to be in the nature of a work-in-progress, and is generally viewed as an important aspect of the ongoing emergence of a globalized knowledge economy. Paralleling the push toward the rise of a globally-integrated knowledge economy, however, there also appear to be important developments driving the growth of a number of different geographical locations as major centers of innovation in various parts of the world. Hence, the emerging global landscape of innovation appears to be marked not only by increasing worldwide integration but also by growing multi-polarity and regionalization.

\section{Conclusion and Implications}

The varied and complex dynamics outlined above hold important implications for business and management. To begin with, in today's changing world, business firms have relatively easy access to (a) increasing amounts of codified knowledge, as well as (b) an expanding international talent pool. At the same time, the accelerating pace of knowledge-production is steadily shrinking product lifecycles. These developments imply not only that firms must prepare themselves for intensifying worldwide competition, but also that competitive success in a rapidly globalizing world might crucially depend upon effective knowledge management at both micro (i.e., individual and firm) and macro (i.e., sectoral, regional, and national) levels (Kim, 2001; Venkitachalam \& Busch, 2012). This implies that developing an effective knowledge management and innovation (KMI) strategy becomes a vital imperative for all firms today. At the level of the firm, a KMI strategy is necessary for strengthening the process of systematic creation, utilization, transfer, storage, and sharing of knowledge with a view to enhancing organizational effectiveness and value creation (Dalkir, 2011; O’Dell \& Hubert, 2011).

Moreover, in view of the relative 'scarcity' of tacit knowledge, a firm's KMI strategy necessarily requires paying enhanced attention to better use and sharing of that particular type of knowledge. In this context, however, there may be a need for firms to realize that ICT can often be a double-edged weapon: on the one hand, ICT can help create added value; on the other hand, by reducing face-to-face interactions, ICT may sometimes have disruptive effects on the sharing of tacit knowledge (Venkitachalam \& Busch, 2012). Hence, while developing their KMI strategy, firms need to design creative ways of limiting the disruptive impact of ICT on tacit knowledge sharing. In our global age, moreover, a firm's KMI strategy needs to duly incorporate appropriate levels of outsourcing/offshoring of innovation and assembly of GINs. In addition to the assembling of GINs, however, as recent research on 'demand-side' approaches to strategy and innovation has pointed out, firms need to develop also the necessary skills and capabilities for accessing the knowledge that might be distributed across different groups of consumers in various countries around the world (Fontana \& Guerzoni, 2008; Wilson \& Doz, 2011). Success in all those enterprises, however, demands not only that firms develop suitable organizational structures and processes, but also that all managements inculcate a global mind-set involving a deep, respectful, and inter-disciplinary understanding of different nations, cultures and economies (Govindarajan \& Gupta, 2000; Prasad \& Prasad, 2006, 2007). Needless to say, in the task of equipping its management with a genuinely global mind-set, the human resource development endeavors of the firm become critically important.

Finally, a firm's KMI strategy also needs to take into consideration the various critiques of knowledge economy that have surfaced in recent years (Kumar, 1995; May, 2002; Webster, 2006). Critics have pointed out, for instance, that although past analyses often celebrated the knowledge economy as promising a future world of relatively non-hierarchical organizations peopled by empowered and well-paid 'knowledge-workers', the reality seems to have turned out to be rather different, because ICT appears to have allowed top managements unprecedented powers of surveillance and control in organizations. Moreover, the globalizing knowledge economy seems to have witnessed two other discouraging developments: (a) the growth of the so-called 'hour-glass organization' (Kumar, 1995), characterized by a few senior executives and knowledge specialists at the very top, a relatively hollow middle, and many more lower level employees, and (b) an "increase in the education premium" (Powell \& Snellman, 2004: 213) leading to widening differences between the earnings of those with the highest educational degrees and the less-educated workers. According to critics, the result of these developments is disempowerment of workers in organizations, and growing polarization of income and wealth in the society. Such criticisms imply that, in order to 
be effective, a firm's KMI strategy needs to be accompanied also by renewed systems of corporate governance, and genuinely meaningful efforts in the area of corporate social responsibility, with a view to successfully addressing the demands and requirements of the firm's multiple stakeholder groups.

\section{References}

Adner, R. (2012). The wide lens: A new strategy for innovation. New York: Penguin.

Appadurai, A. (1996). Modernity at large: Cultural dimensions of globalization. Minneapolis: University of Minnesota Press.

Archibugi, D., \& Iammarino, S. (2002). The globalization of technological innovation. Review of International Political Economy, 9, 98-122. http://dx.doi.org/10.1080/09692290110101126

BACEI. (2012). Technology works: High-tech employment and wages in the United States. San Francisco, CA: Bay Area Council Economic Institute.

Bell, D. (1973). The coming of post-industrial society. New York: Basic Books.

Cassiolato, J., \& Lastres, H. (2011). Science, technology and innovation policies in the BRICS countries. In Cassiolato, J., \& Vitorino, V. (Eds.), BRICS and development alternatives (2011, pp.1-34). New York: Anthem.

Cassiolato, J., \& Vitorino, V. (Eds.). (2011). BRICS and development alternatives: Innovation systems and policies. New York: Anthem.

Castells, M. (2000). The rise of the network society ( $2^{\text {nd }}$ ed.). Malden, MA: Blackwell Publishers.

Dalkir, K. (2011). Knowledge management in theory and practice ( $2^{\text {nd }}$ ed.). Boston, MA: The MIT Press.

Dicken, P. (2003). Global shift: Reshaping the global economic map in the $21^{\text {st }}$ century (4 $4^{\text {th }}$ ed.). New York: Guilford Press.

Dolfsma, W., \& Soete, L. (Ed.). (2005). Understanding the dynamics of a knowledge economy. Northampton, MA: Edward Elgar.

Drucker, P. (1993). Post-capitalist society. New York: Harper.

Ernst, D. (2006). Innovation offshoring (East-West Center Working Papers, No. 90). Honolulu: East-West Center.

Ernst, D., \& Hart, D. (2008). Governing the global knowledge economy. (East-West Center Working Papers, No. 93). Honolulu: East-West Center.

Fontana, R., \& Guerzoni, M. (2008). Incentives and uncertainty: An empirical analysis of the impact of demand on innovation. Cambridge Journal of Economics, 32, 927-946. http://dx.doi.org/10.1093/cje/ben021

Friedman, T. (2005). The world is flat: A brief history of the twenty-first century. New York: Farrar, Strauss and Giroux.

George, G., McGahan, A., \& Prabhu, J. (2012). Innovation for inclusive growth. Journal of Management Studies, 49, 661-683. http://dx.doi.org/10.1111/j.1467-6486.2012.01048.x

Godin, B. (2006). The knowledge-based economy. Journal of Technology Transfer, 31, 17-30.

Govindarajan, V., \& Gupta, A. (2000). Analysis of the emerging global arena. European Management Journal, 18, 274-284. http://dx.doi.org/10.1016/S0263-2373(00)00009-8

Harding, S. (2011). Other cultures' sciences. In S. Harding (Ed.), The postcolonial science and technology studies reader (pp.151-158). Durham, NC: Duke University Press.

Held, D., \& McGrew, A. (Eds.). (2003). The global transformations reader ( $2^{\text {nd }}$ ed.). Cambridge: Polity Press.

IMF. (2013). World economic outlook. Washington, D.C.: International Monetary Fund.

Inda, J. X., \& Rosaldo, R. (Eds.). (2008). The anthropology of globalization: A reader $\left(2^{\text {nd }}\right.$ ed.). Malden, MA: Blackwell Publishers.

Kim, L. (2001). The dynamics of technological learning in industrialization. Malden, MA: Blackwell Publishers.

Kumar, K. (1995). From post-industrial to post-modern society. Malden, MA: Blackwell Publishers.

Kumar, N., \& Puranam, P. (2012). India inside. Boston, MA: Harvard Business Review Press.

Leydesdorff, L. (2006). The knowledge-based economy. Boca Raton, Florida: Universal Publishers.

Lundvall, B-A. (1992). National systems of innovation: Towards a theory of innovation and interactive learning. London: Pinter. 
Lundvall, B-A. (2007). National innovation system: Analytical concept and developmental tool. Industry and Innovation, 14, 95-119. http://dx.doi.org/10.1080/13662710601130863

Machlup, F. (1962). The production and distribution of knowledge in the United States. Princeton, NJ: Princeton University Press.

Maddison, A. (2007). Contours of the world economy. New York: Oxford University Press.

Mathew, G.. E. (2010). India's innovation blueprint. Oxford: Chandos Publishing.

May, C. (2002). The information society: A sceptical view. Cambridge: Polity Press.

Nelson, R. (1993). National innovation systems. New York: Oxford University Press.

NICI. (2011). Towards a more inclusive and innovative India. New Delhi: National Innovation Council of India.

Nonaka, I. (1991). The knowledge-creating company. Harvard Business Review, 69 (6), 96-104.

Nonaka, I. (1994). A dynamic theory of organizational knowledge creation. Organization Science, 5, 14-37. http://dx.doi.org/10.1287/orsc.5.1.14

Nonaka, I., \& Takeuchi, H. (1995). The knowledge-creating company. New York: Oxford University Press.

NSF. (1998). High-tech industries drive global economic activity. Issue Brief (NSF 98-319; July 20). Washington, D.C.: National Science Foundation.

O’Dell, C., \& Hubert, C. (2011). The new edge in knowledge. Hoboken, NJ: John Wiley.

OECD. (2001). The new economy. Paris: Organization for Economic Cooperation and Development.

OECD. (2012). Looking to 2060. Paris: Organization for Economic Cooperation and Development.

Pavitt, K., \& Patel, P. (1999). Global corporations and national systems of innovation. In Archibugi, D., Howells, J., \& Michie, J. (Eds.), Innovation policy in a global economy (pp.94-119). Cambridge: Cambridge University Press.

Polanyi, M. (1966). The tacit dimension. London: Routledge.

Powell, W., \& Snellman, K. (2004). The knowledge economy. Annual Review of Sociology, 30, 199-220. http://dx.doi.org/10.1146/annurev.soc.29.010202.100037

Prasad, A., \& Prasad, P. (2006). Global transitions: The emerging new world order and its implications for business and management. Business Renaissance Quarterly, 1(3), 91-113.

Prasad, A., \& Prasad, P. (2007). Mix, flux and flows: The globalization of culture and its implications for management and organizations. Journal of Global Business Issues, 1, 11-20.

PWC. (2013). The world in 2050: The BRICS and beyond. London: Pricewaterhouse Coopers.

Radjou, N., Prabhu, J., \& Ahuja, S. (2012). Jugaad innovation: Think frugal, be flexible, generate breakthrough growth. New York: Jossey-Bass.

Reich, E. S. (2012). Research in Asia heats up. Nature, 481 (January 26), 420.

USNIC. (2012). Global trends 2030: Alternative worlds. Washington D.C.: United States National Intelligence Council.

Venkitachalam, K., \& Busch, P. (2012). Tacit knowledge. Journal of Knowledge Management, 16, 356-371. http://dx.doi.org/10.1108/13673271211218915

Wallerstein, I. (2000). Globalization or the age of transition? International Sociology, 15, 251-267. http://dx.doi.org/10.1177/0268580900015002007

Webster, F. (2006). Theories of the information society ( $3^{\text {rd }}$ ed.). New York: Routledge.

Wilson, D., \& Purushothaman, R. (2003). Dreaming with BRICs: The path to 2050. Goldman Sachs Global Economics Research Paper Number 99. Retrieved from http://www.gs.com/insight/research/reports/99.pdf

Wilson, K., \& Doz, Y. (2011). Agile innovation: A footprint balancing distance and immersion. California Management Review, 53, 6-26. http://dx.doi.org/10.1525/cmr.2011.53.2.6

World Bank. (2012). World development indicators. Washington, D.C.: World Bank.

World Bank. (2013). World development indicators. Washington, D.C.: World Bank.

WTO. (2012). World trade report. Geneva: World Trade Organization. 